\title{
ISOLATION AND CHARACTERISATION OF TWO STRAINS OF HERPESVIRUS HOMINIS TYPE 1 FROM FALLOPIAN TUBES
}

\author{
I. G. Barton, S. N. Najem, M. J. Walker \\ AND C. W. PotTER
Department of Virology, The University of Sheffield Medical School, Beech Hill Road, Sheffield S10 2RX

\begin{abstract}
Summary. Herpesvirus hominis type 1 (HSV-1) was isolated from fallopian-tube biopsies of two women who were using an intra-uterine contraceptive device; the strains were isolated on different dates and at different hospitals. Both the isolates were shown to be HSV-1 by restriction-enzyme analysis, polypeptide profiles and indirect immunofluorescence; the two isolates could not be distinguished by these tests, but the tests distinguished them from HSV-1 strain 71-15 and HSV-2 strain 333. The viruses were again isolated from samples of fallopiantube tissue stored in liquid nitrogen, and their polypeptide and restriction-enzyme profiles were the same as those of the initial isolates. Virus was not isolated from fallopian-tube samples obtained from other IUD patients undergoing surgery at the same two hospitals at the same time.
\end{abstract}

\section{INTRODUCTION}

Herpesvirus hominis (HSV) is divided into two serotypes, type 1 (HSV-1) and type 2 (HSV-2), which differ clinically in their sites of infection. HSV-1 usually infects the head and neck whilst HSV-2 infects the skin below the waist and usually causes genital lesions. However, the difference in site of infection is not absolute and $22 \%$ of genital HSV lesions were reported to be associated with type-1 serotype (Smith, Peutherer and Robertson, 1976). The two serotypes are genetically very similar (Kieff et al., 1972), but can be distinguished by several methods. Although they can be differentiated by serological techniques, these are often complicated by the considerable degree of antigenic cross reactivity so that biochemical methods are more suitable for typing the virus. The virus serotypes are best differentiated by an analysis of their nucleic acid; the DNAs of type 1 and type 2 exhibit clearly distinguishable DNA-fragment patterns after restriction-enzyme digestion (Skare, Summers and Summers, 1975; Lonsdale, 1979); in addition, many of the virus polypeptides produced in infected cells by the two types can be distinguished by polyacrylamide-gel electrophoresis (Courtney and Powell, 1975). These methods are very discriminating, and can be used to show differences between isolates of a single serotype (Lonsdale et al., 1979). 
HSV-1 and HSV-2 can become latent in nerve ganglia after a primary infection. HSV-1 has been isolated from the trigeminal ganglia in $60 \%$ of cadavers by co-cultivation with susceptible cells (Warren et al., 1977), and virus has been demonstrated in the superior cervical and vagus ganglia (Warren et al., 1978). Latent HSV-2 has been isolated from the sacral ganglia (Baringer, 1974; Linneman et al., 1978). This report describes the isolation and characterisation of two strains of Herpesvirus hominis isolated from fallopian tubes. Restriction-enzyme studies showed the isolates to be identical, but distinct from another strain of HSV-1.

\section{MATERIALS AND METHODS}

Tissue culture. BHK-21 (C13) cells (Flow Laboratories, PO box 17, Irvine, Scotland) were grown as monolayers in Glasgow-modified Eagle's medium containing tryptose-phosphate broth $10 \%(\mathrm{w} / \mathrm{v})$ and newborn-calf serum $10 \%(\mathrm{v} / \mathrm{v})$. Cells were subcultured at regular intervals on a split-ratio basis.

Preparation of virus stocks. Herpesvirus hominis HSV-1 strain 71-15 and HSV-2 strain 333 were obtained from Dr F. Rapp, Milton S. Hershey Medical Center, Pennsylvania, USA. Pools of these viruses were prepared by inoculating confluent cultures of BHK-21 cells, grown in $570-\mathrm{ml}$ glass screw-capped bottles, with virus at a concentration of $0.01-0 \cdot 1$ plaque forming units (pfu)/cell in $1 \mathrm{ml}$ of Eagle's minimal essential medium (EMM) containing $2 \%(\mathrm{v} / \mathrm{v})$ newborn-calf serum. After adsorption at $37^{\circ} \mathrm{C}$ for $1 \mathrm{~h}, 50 \mathrm{ml}$ of EMM were added to each bottle and incubation was continued for $36-48 \mathrm{~h}$. The infected cells were then scraped from the glass surface into the medium, and the cell suspension was sonicated, to release intracellular virus, for $30 \mathrm{~s}$ at full power in an MSE 150-W ultrasonic disintegrator. After cell disruption, the suspension was centrifuged for $10 \mathrm{~min}$ at $200 \mathrm{~g}$, and the supernatant fluid containing the released virus was stored in $1-2 \mathrm{ml}$ portions at $-80^{\circ} \mathrm{C}$.

Titration of virus. For determination of the infectivity titre of the viruses, confluent monolayers of cells in 5-cm plastic petri dishes (Sterilin, 43 Broad Street, Teddington, Middlesex) were inoculated with $0.1 \mathrm{ml}$ of an appropriate dilution of virus. The virus was allowed to adsorb for $1 \mathrm{~h}$ at $37^{\circ} \mathrm{C}$ and then $5 \mathrm{ml}$ of EMM containing $0.8 \%$ carboxymethylcellulose was added to each dish. The dishes were further incubated at $37^{\circ} \mathrm{C}$ in an atmosphere of $5 \%$ $\mathrm{CO}_{2}$ in air for 3-4 days; the cells were then fixed with $10 \%$ formol saline, stained with Leishman's stain and the plaques were counted.

Isolation of viruses from fallopian tubes. All tissue samples were processed on the day of collection. The tissue was finely minced with scissors, homogenised in a Dounce homogeniser and then centrifuged at $5000 \mathrm{~g}$ for $10 \mathrm{~min}$. The pellet was collected and resuspended in EMM then sonicated at full power for $30 \mathrm{~s}$. The sonicate was centrifuged at $1500 \mathrm{~g}$ for $15 \mathrm{~min}$ and inoculated directly onto confluent cultures of BHK-21 cells in 60-ml screw-capped bottles. Cultures were examined daily for cytopathic effect (CPE) and were maintained, with changes of medium every 3-5 days, until the cells degenerated. Bottles of cells with CPE were harvested when $75-100 \%$ of the cells were affected. Samples of tissue were also placed in Hams F 10 medium containing $10 \%$ dimethylsulphoxide, and stored in the vapour phase above liquid nitrogen $\left(-140^{\circ} \mathrm{C}\right)$. The samples were subsequently thawed rapidly at $37^{\circ} \mathrm{C}$, sonicated at full power for $30 \mathrm{~s}$, and inoculated without clarification onto confluent monolayers of BHK-21 cells grown in 120 -ml bottles. The cultures were incubated at $37^{\circ} \mathrm{C}$ and examined daily for CPE; the viruses were harvested when the cells showed $75-100 \% \mathrm{CPE}$ and were passed once more in BHK-21 cells before being used for restriction-enzyme and polypeptide analysis.

Labelling of virus and cellular proteins. The labelling of virus proteins with ${ }^{35} \mathrm{~S}$-methionine $\left({ }^{35} \mathrm{~S}\right.$-met) was performed in the wells of Linbro trays (Flow Laboratories; catalogue number 76-033-05). The wells were each seeded with $5 \times 10^{5}$ BHK-21 cells and incubated overnight at $37^{\circ} \mathrm{C}$. The cells were then infected with virus at a concentration of $20-50 \mathrm{pfu} / \mathrm{cell}$ in $0 \cdot 1 \mathrm{ml}$ of 
EMM, and allowed to adsorb for $1 \mathrm{~h}$ at $37^{\circ} \mathrm{C}$. After adsorption, the cells were washed once with $1 \mathrm{ml}$ of EMM containing one-fifth of the normal concentration of methionine and $2 \%(\mathrm{v} / \mathrm{v})$ newborn-calf serum, and then $0.5 \mathrm{ml}$ of the same medium was added to each well and the trays incubated for $2 \mathrm{~h}$ at $37^{\circ} \mathrm{C}$. The infected cells were then labelled with ${ }^{35} \mathrm{~S}$-met (specific activity $1080 \mathrm{Ci} / \mathrm{mmol}$ ) at $10 \mu \mathrm{Ci} / \mathrm{ml}$ for $21 \mathrm{~h}$.

After incubation in the presence of ${ }^{35} \mathrm{~S}$-met, the medium was removed and replaced by $150 \mu \mathrm{l}$ of buffer of $0.05 \mathrm{M}$ Tris- $\mathrm{HCl}, p \mathrm{H} 6.8$, containing sodium dodecyl sulphate (SDS) $2 \%$, 2-mercaptoethanol $5 \%$, glycerol $10 \%$ and bromophenol blue. The trays were heated at $80^{\circ} \mathrm{C}$ for $10 \mathrm{~min}$ and the contents of the wells were transferred to vials. The samples were then boiled for 2 min, and samples were taken for the determination of trichloracetic acid (TCA)-precipitable radioactivity. The samples were either assayed immediately or stored at $-70^{\circ} \mathrm{C}$ and when subsequently thawed were placed in a boiling-water bath for $1 \mathrm{~min}$ before electrophoresis.

Polyacrylamide-gel electrophoresis was performed on $18 \times 14-\mathrm{cm}$ slab gels consisting either of $8.5 \%$ acrylamide or of a linear $5.5-12.5 \%$ gradient of acrylamide with a $5 \%$ stacking gel; the preparation of these gels has been described elsewhere (Lonsdale et al., 1979). The ratio of acrylamide:bisacrylamide was determined from the relationship, bisacrylamide $(\mathrm{mg} / 100$ $\mathrm{ml})=1300 /$ acrylamide $(\mathrm{g} / 100 \mathrm{ml})$. An upper buffer solution of $0.05 \mathrm{M} \mathrm{HCl}(p \mathrm{H} \mathrm{9.8)}$ containing $0.55 \mathrm{M}$ glycine and $0.1 \%$ SDS, and a lower buffer of $0.01 \mathrm{M} \mathrm{Tris}-\mathrm{HCl}(p \mathrm{H} 8.7)$ were used. Thyroglobulin (mol. wt $\left.330 \times 10^{6}\right)$, bovine serum albumin $\left(\mathrm{mol}\right.$. wt $\left.67 \times 10^{6}\right)$, lactate dehydrogenase (mol. wt $36 \times 10^{6}$ ) and ferritin (mol. wt $18.5 \times 10^{6}$ ) were all obtained from Pharmacia Ltd, Prince Regent Road, Hounslow, Middlesex, and used as markers of migration. Electrophoresis of samples was done at $200 \mathrm{~V}$ for $5-7 \mathrm{~h}$ or $50 \mathrm{~V}$ overnight at room temperature; after this time, the gels were fixed and stained in methanol: water: acetic acid $(50: 50: 7, \mathrm{v} / \mathrm{v} / \mathrm{v})$ containing Kentacid blue $0.2 \%$ (BDH, Fancy Road, Poole, Dorset), and then destained in several changes of methanol: water: acetic acid $(50: 880: 70, \mathrm{v} / \mathrm{v} / \mathrm{v})$. For autoradiography, gels were dried under vacuum, as described by Fairbanks, Levinthal and Reeder (1965), and exposed to Kodak NS 2T film for varying lengths of time.

Preparation of ${ }^{32}$ P-labelled virus DNA. For restriction-enzyme studies, analysis was made of virus nucleic acid; the DNA was labelled with ${ }^{32} \mathrm{P}$, as described by Lonsdale (1979). The number of TCA-precipitable counts was determined on 10- $\mu$ l samples of labelled DNA.

Restriction-enzyme digests, agarose-gel electrophoresis and autoradiography. The restriction endonuclease SmaI was obtained from Boehringer-Mannheim, Bell Lane, Lewes, Sussex. Digests of virus DNA, containing $1-2 \times 10^{4}$ Cerenkov counts $/ \mathrm{min}$ in $50 \mu \mathrm{l}$ of $0.006 \mathrm{M}$ tris- $\mathrm{HCl}$ ( $p \mathrm{H} 7.5$ ) containing $0.006 \mathrm{M} \mathrm{MgCl}_{2}$, and $0.006 \mathrm{M} 2$-mercaptoethanol, were incubated with 1 unit of restriction enzyme for $3 \mathrm{~h}$ at $37^{\circ} \mathrm{C}$. Reactions were stopped by the addition of $5 \mu \mathrm{l}$ of $60 \%$ sucrose containing $0 \cdot 2 \mathrm{M}$ ethylenediaminetetra-acetate (EDTA) $(p \mathrm{H} 7 \cdot 5)$ and bromophenol blue. The samples were electrophoresed in $0.7 \%$ or $1.0 \%$ vertical-slab gels at $1.5-2 \mathrm{~V} / \mathrm{cm}$ overnight, with $0.03 \mathrm{M} \mathrm{NaH}{ }_{2} \mathrm{PO} 4$ and $0.001 \mathrm{M}$ EDTA in $0.036 \mathrm{M}$ Tris solution as buffer. After electrophoresis, the gels were dried overnight at $37^{\circ} \mathrm{C}$, and exposed to Ilford Rapid R type 5 film (Ilford Ltd, Essex) for various lengths of time.

Antisera. Purified immunoglobulin fractions of antisera to HSV-1 (strain MacIntyre VR3) and HSV-2 (strain MS) were obtained from Dako Laboratories, Denmark. The optimal dilution of the sera for use in immunofluorescence tests was determined by titration on virus-infected cells. FITC-conjugated swine anti-rabbit serum was obtained from Nordic Immunologicals (London).

Indirect immunofluorescence. Confluent monolayers of BHK-21 cells grown on coverslips in $10-\mathrm{cm}$ glass petri dishes were infected with virus at a concentration of $5 \mathrm{pfu} / \mathrm{cell}$; after adsorption for $1 \mathrm{~h}$ at $37^{\circ} \mathrm{C}, 10 \mathrm{ml}$ of EMM was added to each petri dish and incubation was continued for $24 \mathrm{~h}$. The coverslips were then washed twice in ice-cold phosphate-buffered saline (PBS) and once in acetone at $-20^{\circ} \mathrm{C}$, and stored in acetone at $-20^{\circ} \mathrm{C}$.

For immunofluorescence tests, the coverslips were air-dried and covered with either rabbit anti-HSV-1 serum at a dilution of 1 in 500 or rabbit anti-HSV-2 serum at a dilution of 1 in 200; the coverslips were then incubated in a moist chamber at $37^{\circ} \mathrm{C}$ for $30 \mathrm{~min}$, washed in PBS, and incubated for a further 30 min with FITC swine anti-rabbit serum diluted 1 in 20 . After these treatments, the coverslips were again washed twice in PBS, then mounted in glycerol: saline $(9: 1)$ and examined under a Zeiss Universal microscope with epifluorescent illumination. 


\section{RESULTS}

\section{Patients}

Biopsies of fallopian tubes were obtained from the two patients. One patient (MW-2) had had histological evidence of pelvic infection, but at the time of sterilisation the pelvic organs were macroscopically normal and there was no evidence of inflammation in the tubal biopsies. The second patient (MW-1) had had a hysterectomy for disfunctional uterine bleeding. The only abnormality found at hysterectomy was a small intramural fibroid. There was no histological evidence of inflammation in the tubal biopsies. The patient had no history of pelvic inflammatory disease. Neither patient had a history of venereal disease and both had negative cervical smears.

\section{Characterisation of viruses}

Restriction-enzyme analysis. The DNA from the two viruses isolated from the fallopian tubes of patients MW-1 and MW-2 and the DNA of HSV- 1 strain 71-15, and HSV-2 strain 333 were each digested with the restriction endonuclease SmaI. The resulting fragments were then separated by electrophoresis in either $0.7 \%$ or $1 \%$ agarose gels, and fragment migration was revealed by autoradiography. The results are shown in figs. 1 and 2. The autoradiographs show that the DNAs of strains $\mathrm{MW}-1$ and $\mathrm{MW}-2$ gave identical patterns, but that they could be differentiated from those of HSV-1 strain 71-15 and HSV-2 strain 333. Previous studies have shown that restriction-enzyme digests of $\mathrm{HSV}-1$ and $\mathrm{HSV}-2$ are quite distinct; a comparison of the patterns from strains $\mathrm{MW}-1$ and $\mathrm{MW}-2$ with those from three other HSV-1 strains, 71-15, KOS and Patton, showed all these to be similar, but unlike that obtained with HSV-2 strain 333. Strains MW-1 and MW-2 are therefore both HSV-1 because the patterns obtained from all five strains contained fragments with mobilities similar to those of strain 71-15. Fragments a, c, g and 1 from HSV-2 strain 333 did not have the same mobility as those from HSV-1 strains (fig. 2). Additionally, HSV-1 strains KOS and Patton had fragments with mobility similar to that of fragment $b$ from strain MW-1. Only the mobility of strain 333 fragment $j$ was found to be similar to that of HSV-1 strains MW-1 and MW-2 fragment i. HSV-2 strain 333 fragment $g$ was found in strains $\mathrm{MW}-1$ and $\mathrm{MW}-2$, HSV-1 strain Patton and HSV-1 strain 71-15. When the restriction-enzyme profiles from the two original clinical isolates were compared with those obtained from virus from tissue stored in liquid nitrogen, the appearance was identical.

Polypeptide analysis. Analysis of the virus polypeptides produced in cells infected with HSV-1 strains MW-1, MW-2 and 71-15 and HSV-2 strain 333 on $8.5 \%$ single-concentration polyacrylamide gels showed that the profile of HSV-1 strains 71-15, MW-1 and MW-2 were very similar but could be differentiated from that of HSV-2 strain 333; thus, polypeptide analysis clearly indicated that the clinical isolates were strains of $\mathrm{HSV}-1$ virus (fig. 3). Analysis of HSV-1 strains $71-15$ and $\mathrm{MW}-2$ on $5-12.5 \%$ linear-gradient polyacrylamide 


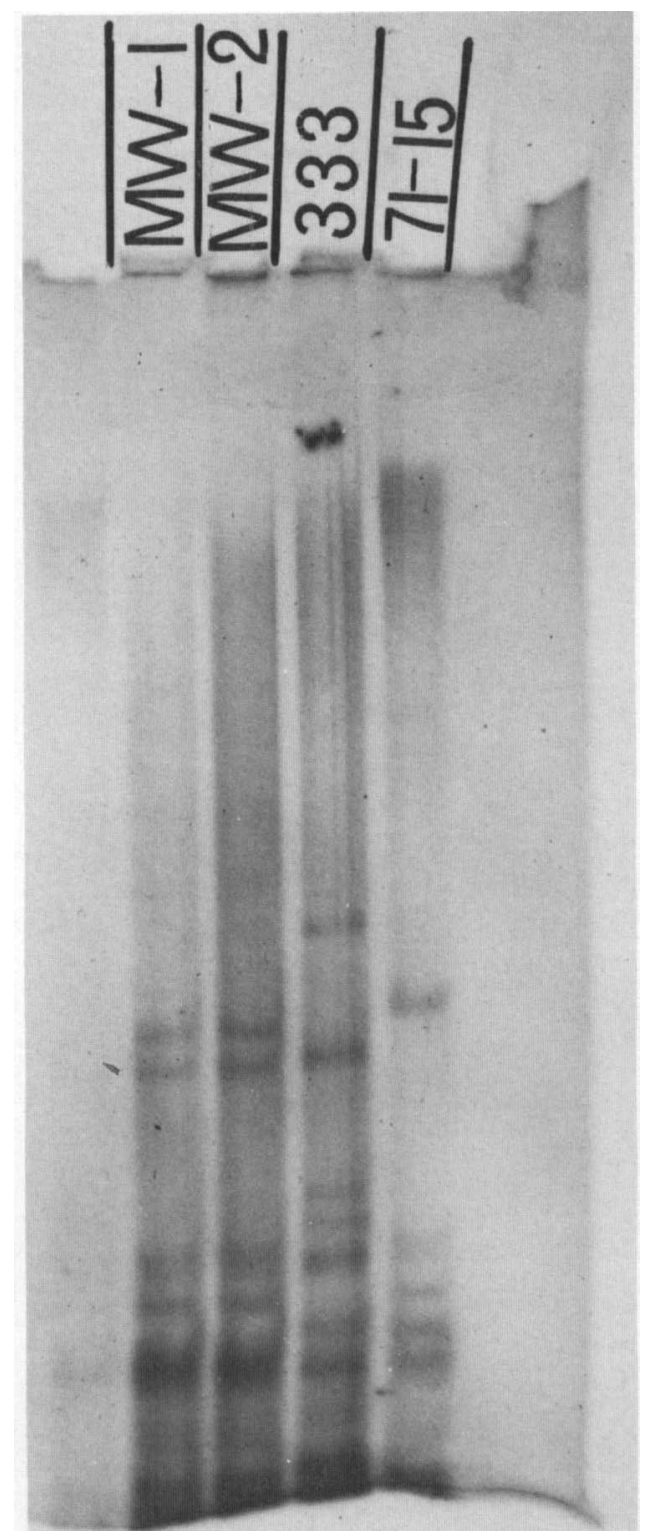

FIG. 1.-Autoradiograph showing SmaI digest of HSV DNA electrophoresed overnight in $0 \cdot 7 \%$ agarose at 2 $\mathrm{V} / \mathrm{cm}$. Fragments of mol. wt $c 5 \times 10^{5}$ have migrated off the bottom of the gel. MW-1 and MW-2 = viruses from fallopian-tube tissue of patients; $333=$ HSV-2 strain $333 ; 71-15=$ HSV -1 strain 71-15. 


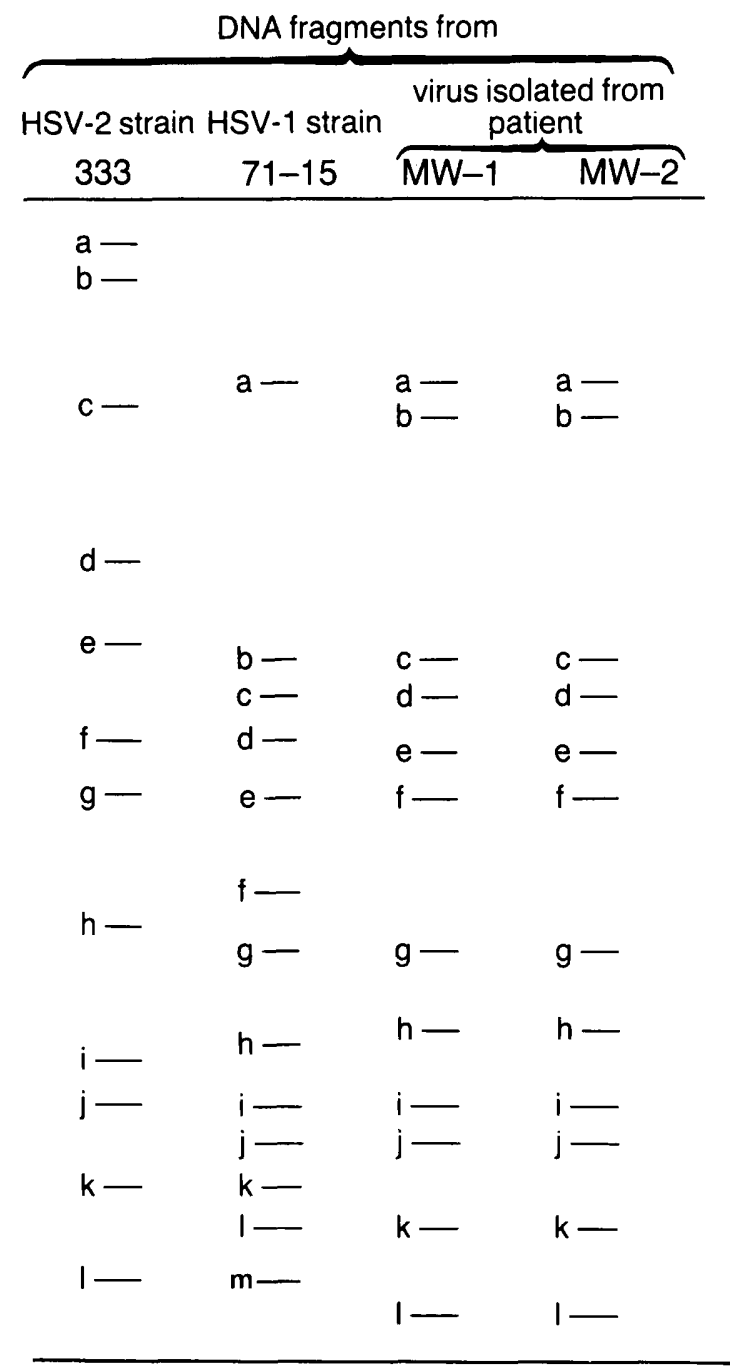

FIG. 2.-Diagram constructed from autoradiographs to show the relative migration of SmaI-digested HSV DNA fragments in $1 \%$ agarose gels.

gels gave better resolution of some polypeptides (fig. 4), and showed that whilst strains MW-1 and MW-2 could not be differentiated there were some minor differences between the two clinical isolates and HSV-1 strain 71-15. Additionally, the polypeptide profiles of the two original clinical isolates and the viruses isolated from tissue stored in liquid nitrogen were indistinguishable.

Immunofluorescence tests. The original isolates and the viruses re-isolated from tissue stored in liquid nitrogen gave fluorescence with $\mathrm{HSV}-1$ antisera diluted 1 in 500 and HSV-2 antisera diluted 1 in 200; control coverslips infected with HSV-1 strain 71-15 and stained with HSV-1 antisera also gave fluorescence, but coverslips infected with HSV-2 strain 333 fluoresced only with HSV-2 antisera. This result further indicated that the two clinical isolates were HSV-1 strains. 


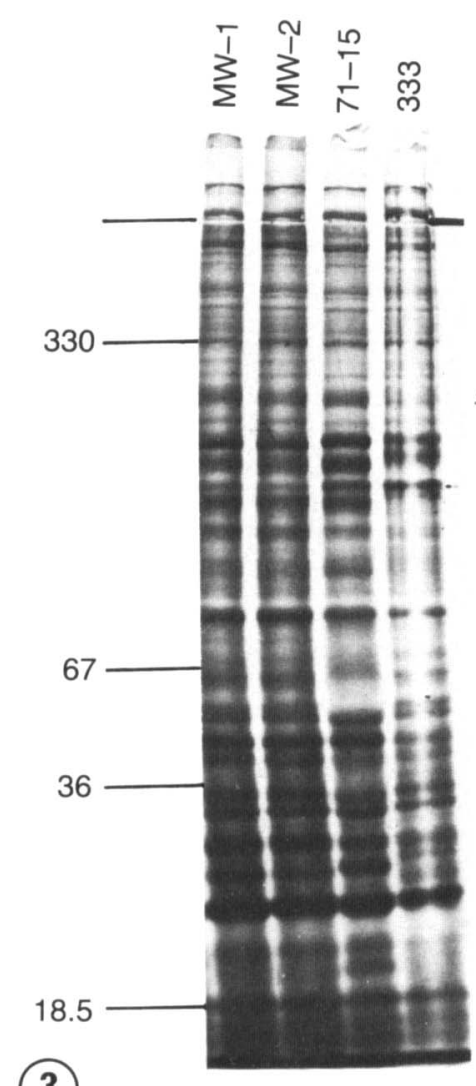

(3)

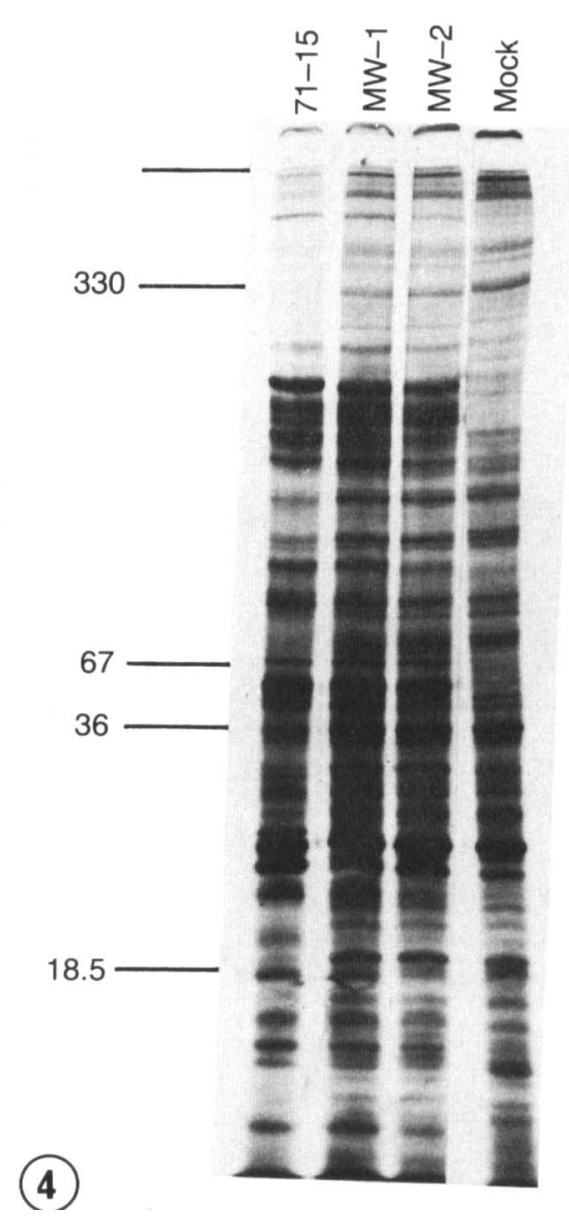

FIG. 3.-Autoradiograph of dried gel to show polypeptides produced in HSV-infected cells labelled 2-21 h after infection with ${ }^{35} \mathrm{~S}$-methionine. Gel was $8.5 \%$ single-concentration polyacrylamide, electrophoresed overnight at $50 \mathrm{~V}$. Strain identification as in fig. 1. Positions of molecular-weight $\left(\times 10^{6}\right)$ markers determined from stained gel are shown.

FIG. 4.-Autoradiograph of infected-cell polypeptides produced as in fig. 3. Gel was $5-12.5 \%$ linear gradient of polyacrylamide. Mock $=$ mock-infected cells; strain identification as in fig. 1 . Positions of molecular-weight $\left(\times 10^{6}\right)$ markers determined from stained gel are shown.

\section{DISCUSSION}

Epidemiological studies have shown that the isolation of HSV-1 from sites below the waist is unusual but not rare (Smith et al., 1976). We report the isolation of HSV-1 from fallopian-tube biopsy of two patients. The viruses were isolated from surgically removed tissue taken by different operators, collected at different times in different hospitals, and processed and tested in the laboratory at different times. In addition, the viruses were re-isolated from samples of tissue that had been stored in liquid nitrogen, but virus was not isolated from other similar samples taken from other patients and stored and 
treated in the same manner. We are confident, therefore, that these are genuine isolates from the patients and not contaminants. The viruses were studied by three techniques to determine the serotype. The results of all three tests clearly indicated that both isolates were strains of HSV-1. Thus, restriction-enzyme analysis of virus DNA and polypeptide profiles indicated that the two viruses were very similar, but distinct from HSV-1 strain 71-15 and from HSV-2 strain 333. Additionally, the restriction-enzyme and polypeptide profiles of the viruses re-isolated from tissue stored in liquid nitrogen were identical to those of the initial isolates.

Previous reports have indicated that HSV-1 isolates from different individuals could be distinguished from each other on the basis of their restriction-enzyme or polypeptide profiles (Lonsdale et al., 1979; Buchman et al., 1978; Buchman, Roizman and Nahmias, 1979). However, Lonsdale et al. (1979) reported that three of their isolates from 17 individuals gave identical profiles. Whilst laboratory contamination cannot be completely excluded from the present results, it is an unlikely explanation of the present findings, because the original tissue was obtained from different sources and processed at different times; in addition, virus was re-isolated from samples of tissue stored in liquid nitrogen. Because HSV-1 strains can be further subtyped by restriction-enzyme analysis of virus DNA (Lonsdale et al., 1979) it is of interest that two isolates from the fallopian tubes of two patients should be identical. This result could indicate that some strains are associated with specific types or sites of infection, and the possibility that specific types are implicated in diseases such as carcinoma of the cervix invites urgent investigation.

However, the technique that we used does not label virus DNA to a very high specific activity, and small or lightly labelled fragments would not have been detected in our studies. Thus, although both the clinical isolates appeared very similar as judged by polypeptide and restriction-enzyme analysis, some minor differences may exist between them.

We thank the Yorkshire Cancer Research Campaign for financial assistance.

\section{REFERENCES}

BARINGER, J. R. (1974). Recovery of herpes simplex virus from human sacral ganglions. New Engl. J. Med. 291, 828.

Buchman, T. G., Roizman, B., Adams, G. and Stover, B. H. (1978). Restriction endonuclease fingerprinting of herpes simplex virus DNA: a novel epidemiological tool applied to a nosocomial outbreak. J. infect. Dis., 138, 488.

Buchman, T. G., Rolzman, B. And Nahmias, A. J. (1979). Demonstration of exogenous genital reinfection with herpes simplex virus type 2 by restriction endonuclease fingerprinting of viral DNA. J. infect. Dis., 140, 295.

COURTNEY, R. J. AND Powell, K. L. (1975). Immunological and biochemical characterization of polypeptides induced by herpes simplex virus types 1 and 2. In Oncogenesis and herpesviruses II, part 1, edited by G. de Thé, M. A. Epstein and H. zur Hausen, International Agency for Research and Cancer Science, Lyons, Publication no. 11, p. 63.

Fairbanks, G., Levinthal, C. and Reeder, R. H. (1965). Analysis of $C^{14}$-labeled proteins by disc electrophoresis. Biochem. biophys. Res. Commun., 20, 393.

KiefF, E., Hoyer, B., Bachenheimer, S. AND RoIzman, B. (1972). Genetic relatedness of type 1 and type 2 herpes simplex viruses. J. Virol., 9, 738. 
Linneman, C. C., Buchman, T. G., Light, I. J., Ballard, J. L. and Roizman, B. (1978). Transmission of herpes-simplex virus type 1 in a nursery for the newborn: identification of viral isolates by DNA "fingerprinting". Lancet, 1, 964 .

LONSDALE, D. M. (1979). A rapid technique for distinguishing herpes-simplex virus type 1 from type 2 by restriction-enzyme technology. Lancet, 1,849 .

Lonsdale, D. M., Brown, S. M., Subak-Sharpe, J. H., Warren, K. G. and Koprowski, H. (1979). The polypeptide and the DNA restriction enzyme profiles of spontaneous isolates of herpes simplex virus type 1 from explants of human trigeminal, superior cervical and vagus ganglia. J. gen. Virol., 43, 151.

Skare, J., Summers, W. P. AND Summers, W. C. (1975). Structure and function of herpesvirus genomes. 1. Comparison of five HSV-1 and two HSV-2 strains by cleavage of their DNA with EcoRl restriction endonuclease. J. Virol., 15, 726.

Smith, I. W., Peutherer, J. F. AND Robertson, D. H. H. (1976). Virological studies in genital herpes. Lancet, 2, 1089.

Warren, K. G., Brown, S. M., Wroblewska, Z., Gil den, D., Koprowski, H. and SubaK-Sharpe, J. (1978). Isolation of latent herpes implex virus from the superior cervical and vagus ganglions of human beings. New Engl. J. Med., 298, 1068.

Warren, K. G., Devlin, M., Gilden, D. H., Wroblewska, Z., Brown, S. M., Subak-Sharpe, J. AND KOPROWSKI, H. (1977). Isolation of herpes simplex virus from human trigeminal ganglia, including ganglia from one patient with multiple sclerosis. Lancet, 2, 637. 